\title{
GOUVERNEUR TEMMING'S PLANTAGE BERG-EN-DAAL BIJ DEN PARNASSUSBERG IN SURINAME \\ DOOR
}

Mr. R. BIJLSMA.

Reeds spoedig na zijne bestuursaanvaarding besloot Gouverneur Temming zich op de hoogte te stellen van den toestand van het bergwerk op den Parnassusberg bij den linkeroever van de Surinamerivier. In Juli 1722 bracht hij daartoe een bezoek aan het mijnwerk, bij welke gelegenheid hij tevens den militairen post ter plaatse inspecteerde. In zijne berichten, aan Directeuren der Societeit van Suriname gezonden, wordt de berg aangeduid als Parnassus- of Blauwe-Berg.

De benaming Parnassusberg was destijds de gebruikelijke in de Gouvernementspapieren. Op de monsterrollen der Surinaamsche militie sedert 1714 treffen wij den term aan, wanneer de sterkte van den militairen post aldaar wordt opgegeven. Anders staat het met den naam Blauwe-Berg. Deze naam is op de kaart van Suriname, uitgegeven bij Ottens te Amsterdam, (verzameling kaarten Algemeen Rijksarchief no. 1667) gesteld bij de hoogte, enkele kilometers ten Noorden van de Marchalskreek aan de Surinamerivier linkeroever gelegen; deze hoogte wordt daar genoemd Param-Hill of BlauweBerg, terwijl er een wachthuis is bijgeteekend. De gelijkstelling Parham-Hill = Blauwe Berg is blijkbaar ontleend aan Herlein's Beschrijving van Suriname, uitgegeven 1718. Wij lezen aldaar:

„Op de Paramhil legt nog een bezettinge, aldus van de Engelsche genoemt, maar van de Nederlanders de Blauwe berg; deze legt aan de westzij van Suriname 21 
mijlen van zee de rivier opwaarts; deze berg is zonder geboomte en ontvangt alzoo de zuivere lugt, dat een grote gezontheid voor de bezettelingen baart, die in getal van vier bestaan en wonen in een zeker huis aldaar opgebouwt; deze wagt is dienstig tegens de opstand der Karaïbanen, indien ze onverwagt mogten opkomen om alzo de blanke te overvallen."

Het is niet duidelijk, welken berg Herlein hier op het oog heeft. Waarschijnlijk heeft Herlein met zijne beschrijving den Parnassusberg bedoeld en combineert zijn boek foutief den naam Parham-Hill met den Blauwen of Parnassusberg en den militairen post op dezen berg sedert 1713.

Gouverneur Temming spreekt dan van den Parnassus- of BlauwenBerg. Zijn bezoek daaraan in den zomer van 1722 had onder meer tot gevolg, dat hij zich een terrein in de nabijheid uitkoos tot het aanleggen van een plantage. In den grondbrief, dien de Gouverneur zich zelven uitreikte, werden hem toegewezen 1500 akkers voor den aanplant van kost (voedingsgewassen), suikerriet, koffie, cacao, indigo, tabak en voor het kanten en zagen van hout; aan de uitgifte was de reserve toegevoegd, dat bij ontdekking van metalen in het terrein deze mijnen het eigendom zouden blijven van de Societeit van Suriname.

In het volgend jaar, 1723, kreeg Gouverneur Temming gelegenheid zijn grondbezit aanmerkelijk te vergrooten. De directeur van het bergwerk op den Parnassusberg kreeg last het mijnwerk te staken, daar het toch niets had opgeleverd. De opstallen van het bergwerk op den Parnassusberg werden daarop onder goedkeuring van Directeuren der Societeit in publieke veiling gebracht met nog 1500 akkers land naast den berg gelegen. Gebouwen en grond werden toegewezen aan Gouverneur Temming, die het hoogste bod deed. Hoewel de verkoopconditiën slechts melding maakten van opstallen aan de bovenkant van den Blauwen- of Parnassusberg, werd de grondbrief geformuleerd alsof behalve de gebouwen ook de Parnassusberg zelf door Temming gekocht was. 
De reserve voor de mijnwerken werd ook in dezen grondbrief opgenomen en tevens was bij den verkoop bepaald, dat de militaire post op den berg zou blijven zoolang het koloniaal gouvernement dien noodig oordeelde.

Bij de 3000 akkers aan de Surinamerivier linkeroever voegde Temming spoedig daarop nog 2000 akkers gelegen aan de overzijde van de rivier; dit nieuwe bezit kwam evenwel niet te staan ten name van Temming, maar op dien zijner dochter Catharina Eleonora en van Mejuffrouw Charlotte Elisabeth van der Lith. ${ }^{1}$ ) In Januari 1725 werd Mejuffrouw van der Lith de echtgenoote van Gouverneur Temming.

Blijkens den staat van Temming's goederen, ter gelegenheid van dit huwelijk opgemaakt, was met den aanleg van de plantage Berg-en-Daal toen reeds een aanvang gemaakt. ${ }^{2}$ ) Na Temmings overlijden in 1727 bleef zijne weduwe de plantage exploiteeren; aanvankelijk had zij daartoe de helft, aan haar stiefdochter Catharina Eleonora Temming toekomend, in huur. Deze verhouding bleef bestaan tijdens het gehuwd zijn van Charlotte Elisabeth van der Lith met Gouverneur Carel Emilius Henry de Cheusses. In 1737 kocht de weduwe Carel de Cheusses vóór haar huwelijk met Gouverneur Joan Raye van haar stiefdochter (welke destijds weduwe was van Gouverneur Jacob Alexander Henry de Cheusses) de helft van de plantage Berg-enDaal, volgens den daarvan opgemaakten inventaris ${ }^{3}$ ).

Blijkens de boedelbeschrijving was Berg-en-Daal toen een suikerplantage. Tot den inventaris behoorden o. a. woonhuis, dienstbodenhuis, molenhuis met paardenstal, dramhuis met dramdistilleerketels; 50 volwassen negers, 32 negerinnen; 78 paarden, 61 stuks hoornvee, 26 schapen, 33 cabrieten, 71 varkens. De gezamenlijke

1) Zie voor de grondbrieven enz. de missive van Gouverneur Temning aan directeuren Societeit van 11 Aug. 1723 en van Gouverneur Mauricius van 25 Jan. 1744.

2) Zie Judicieele Akten 1727-1729 (in Oud-Notarieel Archief) fol. 147.

3) Contract 18 Mei 1737 in Oud-Notar. Archief. 
waarde werd getaxeerd op ruim 71.000 gulden.

De juiste begrenzing van de plantage staat aangegeven op de kaart van Berg-en-Daal, in 1735 vervaardigd door den landmeter De Lavaux voor douairière De Cheusses-van der Lith ${ }^{\mathbf{1}}$ ). Tengevolge van de onzekerheid in Gouverneur Temming's oorspronkelijken rechtstitel van den Parnassusberg ontstond in 1744 een geschil tusschen Gouverneur Mauricius en Mevrouw Charlotte Elisabeth van der Lith, destijds echtgenoote van den franschen predikant Audra. Aanleiding tot dit geschil gaf het transport van enkele zieke mijnwerkers der Mineraalcompagnie naar den militairen post op den Parnassusberg ${ }^{\mathbf{2}}$ ). Deze oneenigheid leidde later tot de deelneming der weduwe Audra (Mevrouw Duvoisin geheeten, na haar huwelijk in 1748 met den franschen predikant D.) aan de bekende cabale tegen Gouverneur Mauricius.

Nog tijdens het leven van Charlotte Elisabeth van der Lith zou Berg-en-Daal als houtgrond worden geëxploiteerd. Dit blijkt uit den boedelinventaris, opgemaakt in November 1753 na het overlijden der Weduwe Duvoisin-Van der Lith, in welke stuk de waarde van Berg-en-Daal op bijna 97.000 gulden werd geschat.

1) Inventaris Kaarten Alg. Rijksarchief no. 1694.

2) Brief van Gouverneur Mauricius aan Directeuren van 25 Jan. 1744 en van Mevrouw Audra aan Directeuren van 12 Febr. 1744. 